\title{
NHE1 has a notable role in metastasis and drug resistance of T-cell acute lymphoblastic leukemia
}

\author{
EHTISHAM ALTAF $^{1 *}$, XIAOXING HUANG $^{1 *}$, JIE XIONG $^{1}$, XIANGYONG YANG $^{2}$, \\ XINZHOU DENG ${ }^{1}$, MENG XIONG $^{1}$, LU ZHOU $^{3}$, SHAN PAN $^{1}$, WEN YUAN ${ }^{1}$, XINRAN LI $^{1}$, \\ LING HAO $^{1}$, KINGSLEY MIYANDA TEMBO ${ }^{1}$, RUIJING XIAO ${ }^{1}$ and QIUPING ZHANG ${ }^{1}$ \\ ${ }^{1}$ Department of Immunology, School of Basic Medical Sciences, Wuhan University, Wuhan, Hubei 430071; \\ ${ }^{2}$ Department of Bioengineering, Hubei University of Technology Engineering and Technology College, \\ Wuhan, Hubei 430068; ${ }^{3}$ Department of Hematology, Taihe Hospital, Shiyan, Hubei 442000, P.R. China
}

Received January 22, 2016; Accepted May 4, 2017

DOI: $10.3892 / 01.2017 .6716$

\begin{abstract}
T-cell acute lymphoblastic leukemia (T-ALL) represents a spectrum of hematological malignancies that affect human health. Metastasis and chemotherapeutic drug resistance are the primary causes of mortality in patients with T-ALL. Sodium-hydrogen antiporter 1 (NHE1) is established to serve a role in metastasis and drug resistance in numerous types of cancer; however, the function of NHE1 in T-ALL remains to be elucidated. Previously, the C-C-motif chemokine ligand 25 (CCL25) was identified to be involved in metastasis and drug resistance in the MOLT4 T-ALL cell line, as was the ezrin protein. The present study investigated the role of NHE1 in the metastasis of T-ALL using a Transwell assay and scanning electron microscopy, using MOLT4 cells as a model. The association between NHE1 and ezrin was assessed using laser scanning confocal microscopy. The effect of NHE1 on resistance to the chemotherapy drug doxorubicin (DOX) was also investigated using a cell viability and cytotoxicity assay. Expression of NHE1 increased following treatment with CCL25, accompanied by morphological changes in MOLT4 cells and the co-localization of NHE1 with ezrin. In addition,
\end{abstract}

Correspondence to: Professor Qiuping Zhang or Dr Ruijing Xiao, Department of Immunology, School of Basic Medical Sciences, Wuhan University, 185 Donghu Road, Wuchang, Wuhan, Hubei 430071, P.R. China

E-mail: qpzhang@whu.edu.cn

E-mail: xrj7619@aliyun.com

Abbreviations: T-ALL, T-cell acute lymphoblastic leukemia; NHE1, sodium hydrogen antiporter 1; DOX, doxorubicin; ERM, ezrin/radixin/moesin

*Contributed equally

Key words: sodium-hydrogen antiporter 1, T-cell acute lymphoblastic leukemia, MOLT-4 cells, C-C-motif chemokine ligand 25, ezrin, polarization, drug resistance wild-type MOLT4 cells exhibited an increased polarization ability compared with NHE1- or ezrin-silenced cells. NHE1or ezrin-silenced cells exhibited higher sensitivity to DOX compared with wild-type MOLT4 cells. In conclusion, the increased expression or activity of NHE1 may potentially be a poor prognostic indicator for human T-ALL.

\section{Introduction}

T-cell acute lymphoblastic leukemia (T-ALL) is a subset of acute leukemia and an aggressive hematological malignancy. T-ALL has the propensity to metastasize to other organs of the body. Chemokines and their receptors have been established to be important contributors to the metastatic potential of tumors $(1,2)$. The interplay between chemokines, cells and the microenvironment is complex and involves numerous other cellular molecules, including ezrin/radixin/moesin and nuclear factor of activated $\mathrm{T}$ cells. Sodium-hydrogen antiporter 1 (NHE1) is a molecule that may interact with the cellular cytoskeleton and aid the formation of signaling complexes, in addition to having an ion exchange function $(3,4)$. NHE1 is a transmembrane protein that consists of twelve segments and extrudes a $\mathrm{H}^{+}$in exchange for an extracellular $\mathrm{Na}^{+}$; it is involved in the regulation of cellular $\mathrm{pH}$, ion composition and cellular volume (5), thereby serving a role in diseases associated with the heart, blood vessels and kidneys (6). NHE1 is also involved in enzyme activation that degrades the extracellular matrix and is therefore produced by invasive tissues, including breast cancer cells $(7,8)$. NHE1 is localized in the lamellipodia of fibroblast cells, where it acts as an anchor at the cell membrane for cellular cytoskeleton by directly binding to the ezrin/radixin/moesin (ERM) family of actin-binding proteins (9). The ERM family is established to be important molecules in cytoskeletal activity as they link actin to the plasma membrane proteins. ERMs are frequently identified to be highly expressed in numerous cancer types and are important mediators of cell survival signaling (10-12). Previous studies have suggested that high ezrin expression may be associated with cellular motility, therefore having a role in metastasis and invasion (13-15). ERM proteins have previously been identified to be important 
in T-ALL drug resistance with ezrin, an important molecule in C-C-motif chemokine ligand 25 (CCL25)-induced T-ALL metastasis $(12,16)$.

The role of chemokines in cancer has been the focus of a substantial amount of previous research. C-C chemokine receptor type 9 (CCR9) is a G-protein-coupled receptor that is primarily expressed on immature $\mathrm{T}$ cells, with restricted expression in mature T cells $(17,18)$. CCR9 has been identified to be important in T-cell development and T-cell tissue-specific homing once it is bound to its specific ligand CCL25 (12). A previous study indicated that CCR9 is highly expressed in the T-ALL MOLT4 cell line and also that CCL25 induces chemotherapeutic drug resistance in T-ALL (19) and effectively polarizes MOLT4 cells with ERM redistribution (12).

In addition, NHE1 activity has the ability to induce chemotherapeutic resistance against drugs, including DOX and imatinib, in renal and other cancer types (3,20-22). These results suggest that NHE1 has a vital role in cell survival and proliferation.

Using the T-ALL MOLT4 cell line as a model, the present study investigated whether NHE1 has a role in the metastatic transformation of MOLT4 cells and whether ezrin associates with NHE1 in metastatic MOLT4 cells.

\section{Materials and methods}

Cell culture. The human T-ALL MOLT4 cell line was obtained from American Type Culture Collection (Manassas, VA, USA). Ev-ve MOLT4 cells (ezrin-silenced MOLT4 cells) were generated as previously reported (16). The cells were maintained in RPMI 1640 medium (Gibco; Thermo Fisher Scientific, Inc., Waltham, MA, USA) supplemented with $10 \%$ fetal bovine serum (FBS; Hyclone; GE Healthcare, Logan, UT, USA) and cultured in a $5 \% \mathrm{CO}_{2}$ air incubator at $37^{\circ} \mathrm{C}$.

NHE1 short interfering (si)RNA transfection. The transfection was performed using Lipofectamine 2000 reagent (Thermo Fisher Scientific, Inc.) according to the manufacturer's protocol in MOLT4 cells. In brief, the cells were suspended in serum-free RPMI 1640 medium and plated in 6-well plates at a density of $5 \times 10^{5}$ cells $/ \mathrm{ml}, 2 \mathrm{ml}$ per well. A total of $2 \mu \mathrm{l}$ siRNA $(100 \mathrm{mmol} / \mathrm{ml})$ was added to each well. Following incubation for $8 \mathrm{~h}, 200 \mu \mathrm{l} \mathrm{FBS}$ was added to each well. The cells were incubated at $37^{\circ} \mathrm{C}$ for $48 \mathrm{~h}$ and used for further experiments. The siRNA sequences were as follows: NHE1 sense, 5'-GAU AGGUUUCCAUGUGAUCTT-3' and anti-sense, 5'-GAUCAC AUGGAAACCUAUCTT-3'; and negative control (scrambled) sense, 5'-UUCUCCGAACGUGUCACGUTT-3' and anti-sense, 5'-ACGUGACACGUUCGGAGAATT-3'.

Cariporide treatment. The MOLT4 cells were plated on 6 -well plates at a density of $5 \times 10^{5}$ cells $/ \mathrm{ml}, 2 \mathrm{ml}$ per well. The cells were treated with $20 \mu \mathrm{M}$ cariporide (Santa Cruz, Biotechnology, Inc., Dallas, TX, USA) and incubated for $24 \mathrm{~h}$ in RPMI 1640 medium with $10 \%$ FBS prior to use in the Transwell chamber assay.

RNA extraction and reverse transcription-polymerase chain reaction ( $R T-P C R)$. Total RNA was extracted from MOLT4 cells using TRIzol (Invitrogen; Thermo Fisher Scientific, Inc.) according to the manufacturer's protocol and quantified using NanoDrop 2000 (Thermo Fisher Scientific, Inc.). A total of $2 \mu \mathrm{g}$ RNA was reverse-transcribed to cDNA with random primers using the Reverse Transcription system (MyCycler ${ }^{\mathrm{TM}}$ thermal cycler, Bio-Rad Laboratories, Inc., Hercules, CA, USA), according to manufacturer's protocol. RT-PCR was performed with the Takara RNA PCR kit (Takara Bio, Inc., Otsu, Japan). The primer sequences were as follows: NHE1 forward, 5'-GCC TTCTCTCTGGGCTACCT-3' and reverse, 5'-CTTGTCCTT CCAGTGGTGGT-3'. The PCR thermocycling protocol was as follows: $95^{\circ} \mathrm{C}$ for $1 \mathrm{~min}$ and then 35 cycles of $95^{\circ} \mathrm{C}$ for $30 \mathrm{sec}$, annealing at $64^{\circ} \mathrm{C}$ for $30 \mathrm{sec}$ and elongation at $72^{\circ} \mathrm{C}$ for $30 \mathrm{sec}$ followed by $95^{\circ} \mathrm{C}$ for $5 \mathrm{~min}$ once at the end of protocol. The PCR products were separated by $1.5 \%$ agarose gel electrophoresis and visualized under ultraviolet light following staining with ethidium bromide.

Protein extraction and western blot analysis. The cells were washed with PBS and lysed with radioimmunoprecipitation assay lysis and extraction buffer (Thermo Fisher Scientific, Inc.) containing protease inhibitor (1 $\mathrm{mM}$ phenylmethylsulfonyl fluoride; Thermo Fisher Scientific, Inc.). The total protein concentration was measured using the Pierce Bicinchoninic Acid Protein Assay kit (Thermo Fisher Scientific, Inc.) on the PerkinElmer 2030 VICTOR X Multilabel Plate Reader (PerkinElmer, Inc., Waltham, MA, USA). Whole-cell lysates were boiled at $100^{\circ} \mathrm{C}$ for $5 \mathrm{~min}$ in equal volumes of loading buffer (Beyotime Institute of Biotechnology, Haimen, China). All samples (15 $\mu$ l per lane) were subjected to $10 \%$ SDS-PAGE and transferred to PVDF membranes. Subsequent to blocking for $2 \mathrm{~h}$ at room temperature in TBS-Tween 20 (TBST) containing 5\% skimmed milk to block membranes, the membranes were incubated with anti-NHE1 (dilution, 1:1,000; catalog no., ab67314; Abcam, Cambridge, MA, USA) and anti-ezrin (dilution, 1:500; catalog no., ab41672; Abcam) primary antibodies diluted in TBST containing 5\% non-fat milk with gentle shaking at $4^{\circ} \mathrm{C}$ overnight. Subsequent to washing three times, the membranes were incubated with the 1:200 horseradish peroxidase-conjugated secondary antibodies (dilution, 1:200; catalog no., GB23303; Wuhan Biological Technology Co., Ltd., Wuhan, China) for $2 \mathrm{~h}$ at room temperature. The signals were detected using an Enhanced Chemiluminescence Detection kit (Thermo Fisher Scientific, Inc.).

Scanning electron microscopy assay. The MOLT4 cells were overlaid on coated coverslips and fixed with $2.5 \%$ glutaraldehyde in PBS overnight at $4^{\circ} \mathrm{C}$. Following a PBS wash, the cells were fixed in $1 \%$ osmium tetroxide at $4^{\circ} \mathrm{C}$ for $2 \mathrm{~h}$ and washed thoroughly with distilled water. Subsequently, the post-fixed specimens were dehydrated using a graded series of ethanol and then transferred to a graded series of t-butyl alcohols (freezing point $25.4^{\circ} \mathrm{C}$ ), the t-butyl alcohol substituted specimens were freeze-dried at $15^{\circ} \mathrm{C}$ and at high vacuum (23). The experimental specimens were sputter-coated with platinum and then observed using a scanning electron microscope (S-750; Hitachi, Ltd., Tokyo, Japan) operating at $20 \mathrm{kV}$ (24).

Laser confocal microscopy assay. The MOLT4 cells were overlaid on glass slides, fixed at $4^{\circ} \mathrm{C}$ in $4 \%$ paraformaldehyde, 


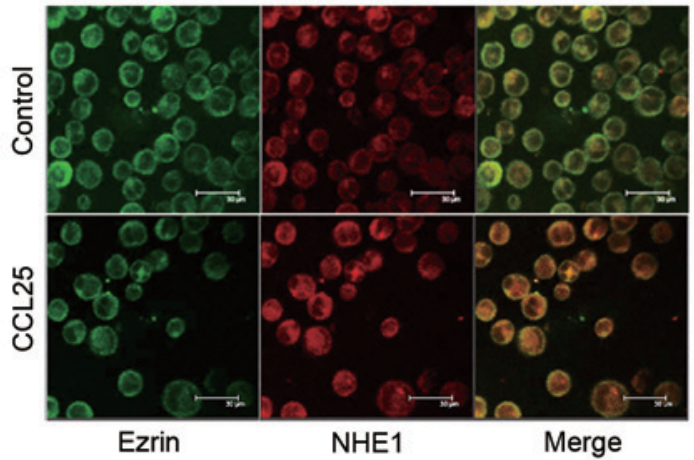

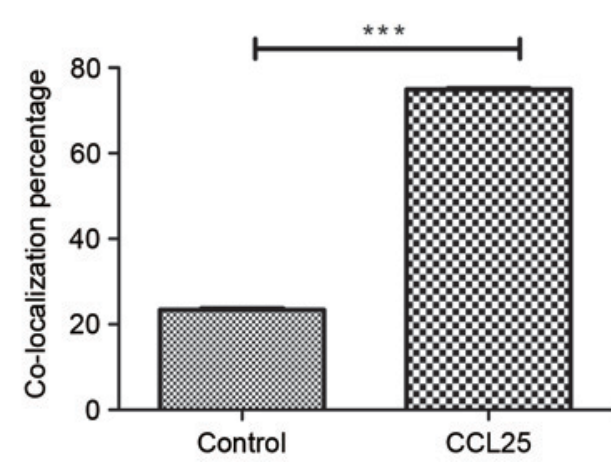

Figure 1. Co-localization of NHE1 and ezrin in CCL25-treated MOLT4 cells using laser scanning confocal microscopy. (A) The subcellular localizations of NHE1 (red) and ezrin (green) in MOLT4 cells treated with CCL25 (100 ng/ml for $10 \mathrm{~min}$ ) was observed. The image demonstrates that NHE1 and ezrin are co-localized in CCL25 treated cells. Scale bar, $30 \mu \mathrm{m}$. (B) Statistical results of NHE1 and ezrin co-localization ratio in control- and CCL25-treated MOLT4 cells ( $\mathrm{n}=5$ fields of view, $\left.{ }^{* * *} \mathrm{P}<0.001\right)$. NHE1, sodium-hydrogen antiporter 1; CCL25, C-C-motif chemokine ligand 25.

permeabilized at $4^{\circ} \mathrm{C}$ with $0.1 \%$ Triton $\mathrm{X}-100$ and then blocked for $1 \mathrm{~h}$ with $3 \%$ bovine serum albumin (Gibco; Thermo Fisher Scientific, Inc.) at room temperature. The cells were incubated with 1:1,000 anti-NHE1 (catalog no., ab67314; Abcam) and 1:500 anti-ezrin (catalog no., ab41672; Abcam) antibodies at $4^{\circ} \mathrm{C}$ overnight. Later, Alexa Fluo ${ }^{\circledR} 488$ donkey anti-rabbit IgG (H+L) (dilution, 1:200; catalog no., ANT024; AntGene Biotechnology Co., Ltd., Wuhan, China) and Alexa Fluo ${ }^{\circledR}$ 594 donkey anti-rabbit IgG $(\mathrm{H}+\mathrm{L})$ (dilution, 1:200; catalog no., ANT030; AntGene Biotech Co., Ltd.) secondary antibody was added to the cells and incubated for $2 \mathrm{~h}$ at room temperature. Experimental specimens were observed using a LCS-SP2-MP-AOB laser confocal scanning microscope (Leica Microsystems GmbH, Wetzlar, Germany).

Transwell assay. The chemotaxis assay was performed in a 24-Transwell chamber (Corning Costar, USA). In brief, MOLT4 cells $\left(100 \mu \mathrm{l}, 1 \times 10^{6}\right.$ cells $\left./ \mathrm{ml}\right)$ were suspended in RPMI 1640 medium containing $0.1 \%$ FBS and added to the upper chamber of the Transwell, which was separated from the lower well by a 8- $\mu \mathrm{m}$ pore-size polycarbonate membrane. CCL25 (100 ng/ml; Cedarlane Laboratories, Burlington, Canada) in RPMI 1640 medium containing $0.1 \%$ FBS was placed in the lower wells, at a quantity of $600 \mu \mathrm{l}$ per well. The cells were allowed to migrate for $24 \mathrm{~h}$ at $37^{\circ} \mathrm{C}$ with $5 \% \mathrm{CO}_{2}$ atmosphere. After $24 \mathrm{~h}$, cells in the lower chamber were counted under a light microscope with a blood counting chamber at $\times 400$ magnification, and five fields were counted for each group of cells.

Flow cytometry. MOLT4 cells $\left(5 \times 10^{5}\right.$ cells $\left./ \mathrm{ml}\right)$ were treated with $0.5 \mu \mathrm{g} / \mathrm{ml} \mathrm{DOX}$, incubated at $37^{\circ} \mathrm{C}$ for $48 \mathrm{~h}$ and then treated with $100 \mathrm{ng} / \mathrm{ml} \mathrm{CCL} 25$ for $10 \mathrm{~min}$ at $37^{\circ} \mathrm{C}$. Untreated MOLT4 cells were used as controls. The cells were washed twice with ice-cold PBS and resuspended in $300 \mu \mathrm{l}$ PBS for flow cytometric analysis (CytoFLEX; Beckman Coulter, Inc., Brea, CA, USA). The excitation wavelength for the cells was $488 \mathrm{~nm}$ and the emission wavelength was $590 \mathrm{~nm}$.

Cell proliferation assay. MOLT4 cells $\left(1 \times 10^{5}\right.$ cells $\left./ \mathrm{ml}\right)$ were plated on 96-well plates in triplicate alongside a control group. The cells were incubated with DOX $(0.5 \mathrm{mg} / \mathrm{ml}$ or $1 \mathrm{mg} / \mathrm{ml})$ at $37^{\circ} \mathrm{C}$ for $48 \mathrm{~h}$ and then $10 \mu \mathrm{l}$ Cell Counting Kit- 8 solution (catalog no., CK04; Dojindo Molecular Technologies, Inc., Kumamoto, Japan) was added per sample for $3 \mathrm{~h}$. Readings were taken at a wavelength of $450 \mathrm{~nm}$ in a spectrometer and cellular survival was calculated accordingly. All the steps were performed according to the manufacturer's protocol.

Statistical analysis. Statistical analysis was conducted using GraphPad Prism v5.0 (GraphPad Software, Inc., La Jolla, CA, USA). Values are presented as the mean \pm standard deviation of $>3$ independently conducted experiments. Statistical significance was assessed by t-test followed by paired comparisons. $\mathrm{P}<0.05$ was considered to indicate a statistically significant difference.

\section{Results}

Co-localization of NHE1 and ezrin. The co-localization of NHE1 and ezrin was observed in MOLT4 cells following stimulation with $100 \mathrm{ng} / \mathrm{ml} \mathrm{CCL25}$ for $10 \mathrm{~min}$, but this was not observed in the control group (Fig. 1A). Statistical analysis (Fig. 1B) identified that the degree of cell co-localization was significantly increased in the CCL25-treated group compared with that in the control group. This observation highlights the role of CCL25 in initiating cellular migration and the association between NHE1 and ezrin indicated by their co-localization.

NHE1 and ezrin silencing. The western blot analysis results revealed that the expression level of ezrin in Ev-negative MOLT4 cells was lower than wild-type MOLT4 cells (Fig. 2A). At the same time, NHE1 siRNA was used to reduce the expression of NHE1 in MOLT4 cells (Fig. 2B).

MOLT4 cell polarization is introduced by CCL25. CCL25 introduces microvillus resorption and polarization in MOLT4 cells (Fig. 2C). The formation of pseudopodia or lamellipodia is associated with cellular invasive or migratory capability (25). The present study assessed this ability in MOLT4 cells through the introduction of CCL25 to assess whether there were any significant morphological alterations. 
A

C

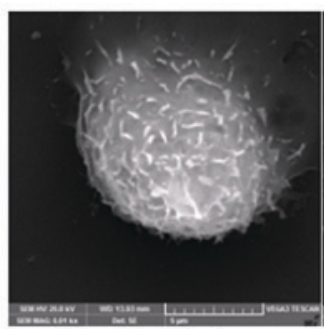

Control

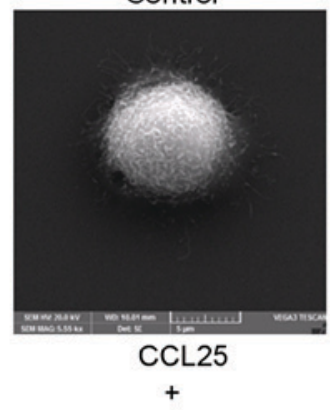

NHE1 SIRNA
B

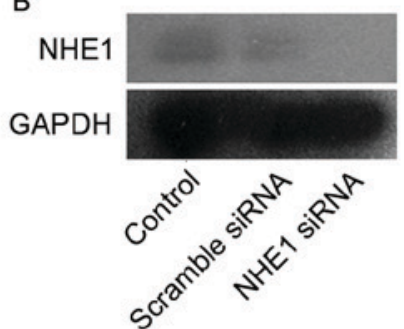

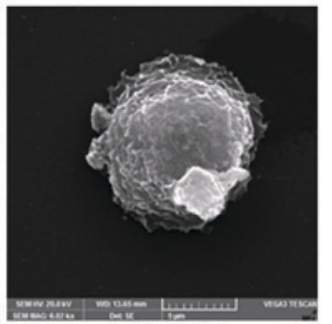

$\mathrm{CCL} 25$

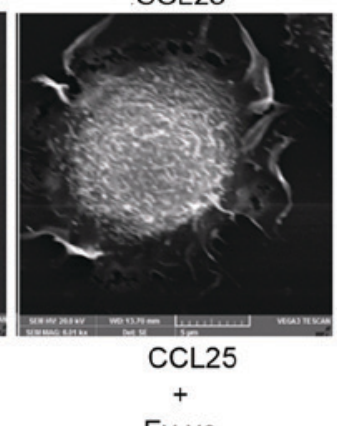

Ev-ve

D

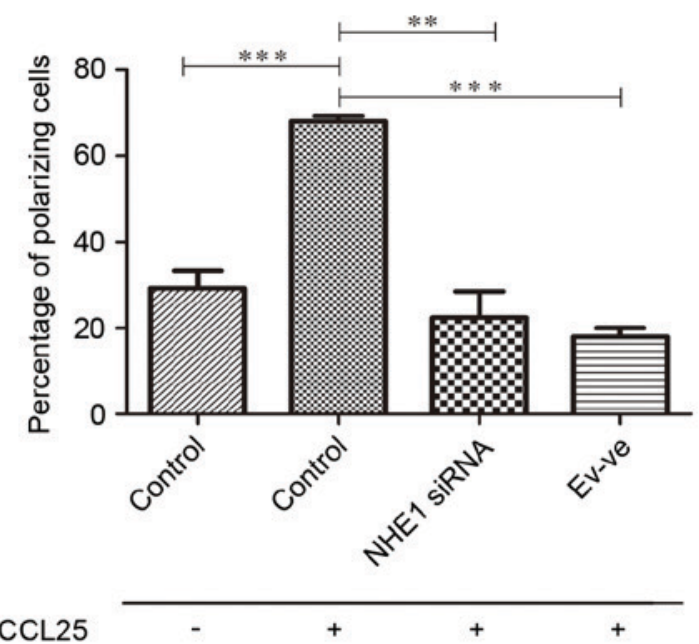

Figure 2. CCL25-induced polarization is inhibited by NHE1 and ezrin silencing. (A) Expression of ezrin protein in MOLT4 and Ev-ve MOLT4 cells assessed using western blot analysis. (B) Expression of NHE1 protein in MOLT4 and NHE1-silenced MOLT4 cells assessed using western blot analysis. (C) The CCL25-induced polarization of MOLT4 cells was inhibited by NHE1 and ezrin silencing, as detected using scanning electron microscopy. (D) The percentage of polarizing cells in the 4 groups under the indicated conditions. The results represent the mean of 3 independent experiments. ${ }^{* *} \mathrm{P}<0.005,{ }^{* * * *} \mathrm{P}<0.001$. siRNA, short interfering RNA; Ev-ve, cells silenced with ezrin-targeted siRNA; NHE1, sodium-hydrogen antiporter 1; CCL25, C-C-motif chemokine ligand 25.

A scanning electron microscopy was used for this experiment. A total of $100 \mathrm{ng} / \mathrm{ml} \mathrm{CCL25}$ was introduced to MOLT4 cells for $10 \mathrm{~min}$. Without stimulation, the MOLT4 cells primarily

A

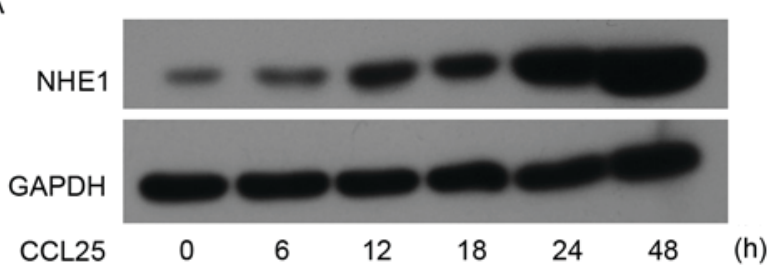

B

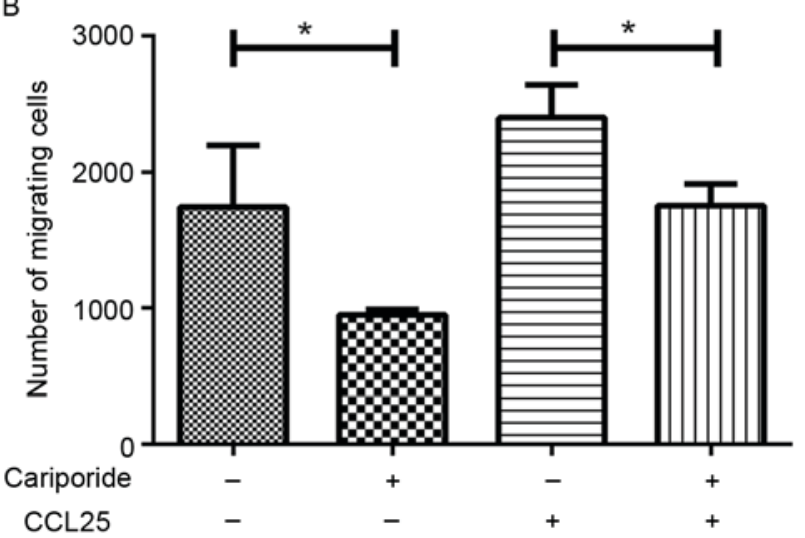

Figure 3. Effect of NHE1 on CCL25-induced migration of MOLT4 cells. (A) Expression of NHE1 in MOLT4 cells when exposed to $100 \mathrm{ng} / \mathrm{ml}$ CCL25 for the indicated time points, as assessed using western blot analysis. (B) The effect of NHE1 silencing and CCL25 on MOLT4 cells migration by Transwell assay $\left(\mathrm{n}=3 ;{ }^{\prime} \mathrm{P}<0.05\right)$. NHE1, sodium-hydrogen antiporter 1 ; CCL25, C-C-motif chemokine ligand 25

exhibit numerous microvilli of differing lengths, extending from the membrane, and a spherical body shape (Fig. 2C). After 10 min of CCL25 stimulation, substantial morphological alterations were observed in wild-type MOLT4 cells (Fig. 2C). The majority of these cells had microvilli, tail-like membrane extensions, ruffled edges and/or pseudopodia-like structure formation in a certain direction due to polarization.

NHE1 silencing reduces CCL25-induced polarization in MOLT4 cells. When compared to the wild-type MOLT4 cells treated with CCL25 (100 ng/ml for $10 \mathrm{~min})$, the NHE1-silenced cells treated with CCL25 with the same conditions exhibited less polarization. The majority of cells in NHE1 siRNA group exhibited an oval shape with no or minimal microvilli and lamellipodia (Fig. 2C).

Ezrin silencing reduces CCL25-induced polarization in MOLT4 cells. Ezrin, a member of the ERM protein family that links the actin cytoskeleton to the plasma membrane, was also identified to be important in cellular migration. Absence or deficiency of ezrin in the Ev-ve MOLT4 group demonstrated decreased polarizing capacity. The ezrin-negative MOLT4 cells treated with CCL25 exhibited a spherical profile with microvilli, compared with wild-type MOLT4 cells treated with CCL25 which exhibited a state of polarization (Fig. 2C). The general absence of polarization morphology in this group of cells emphasizes the involvement of the ezrin protein in migratory ability of MOLT4 cells. Fig. 2D demonstrates that NHE1 and ezrin expression are statistically associated with increased degrees of MOLT4 cell polarization. 
A

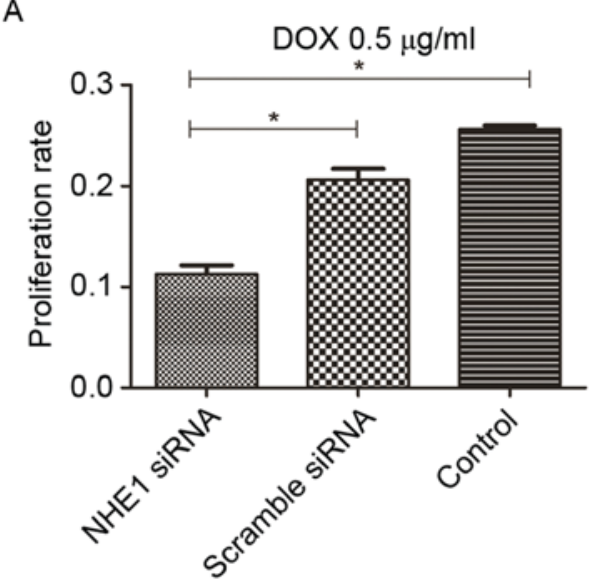

C

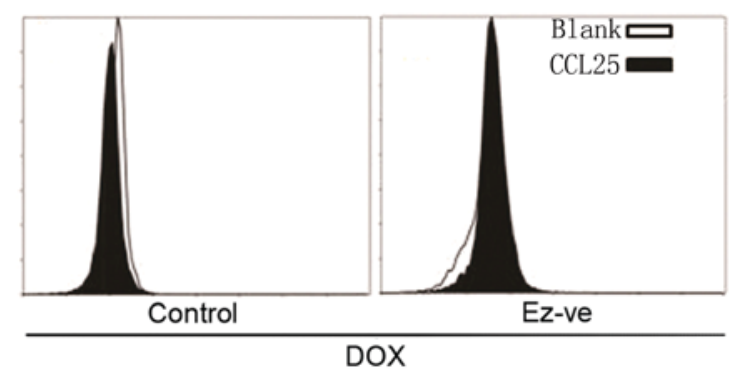

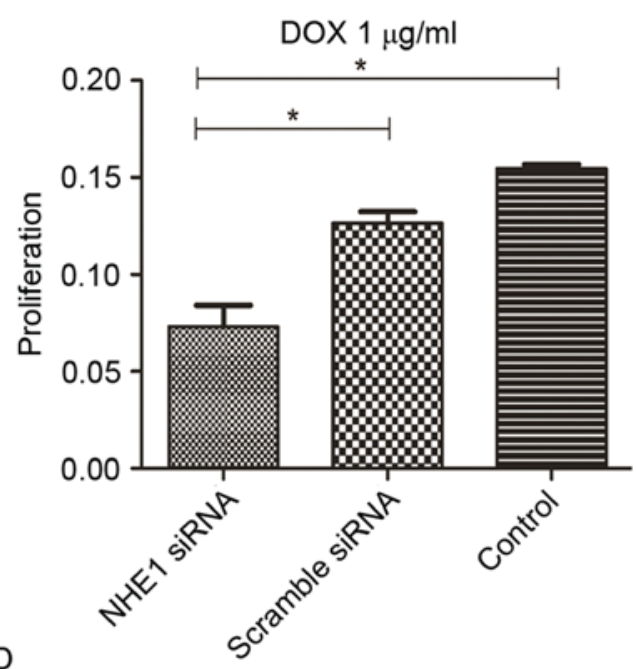

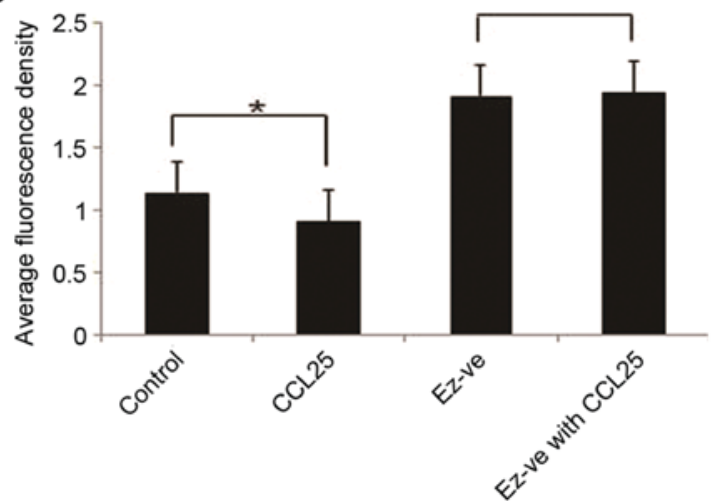

Figure 4. Effect of NHE1 and ezrin on drug resistance of MOLT4 cells. (A and B) Cell proliferation in wild-type, scramble siRNA-treated and NHE1 siRNA-treated MOLT4 cells incubated with (A) $0.5 \mathrm{mg} / \mathrm{ml}$ or (B) $1 \mathrm{mg} / \mathrm{ml}$ DOX. ( $\mathrm{n}=3,{ }^{*} \mathrm{P}<0.05$ ) (C) Drug accumulation in wild-type and ezrin-silenced MOLT4 cells using flow cytometry. (D) The effect of ezrin silencing and CCL25 on drug resistance of MOLT4 cells was detected using flow cytometry. The average fluorescence density represents DOX accumulation in MOLT4 cells. $\left(n=3\right.$; $\left.{ }^{*} \mathrm{P}<0.05\right)$. siRNA, short interfering RNA; Ev-ve, cells silenced with ezrin-targeted siRNA; NHE1, sodium-hydrogen antiporter 1; CCL25, C-C-motif chemokine ligand 25; DOX, doxorubicin.

CCL25 stimulation induces the increased expression of NHE1 in MOLT4 cells. Fig. 3A presents the NHE1 expression levels following $100 \mathrm{ng} / \mathrm{ml}$ CCL25 treatment in wild-type MOLT4 cells. The protein was isolated at $6,12,18,24$ and $48 \mathrm{~h}$ following CCL25 treatment. These results indicated that NHE1 expression increased following exposure to CCL25 in a time-dependent manner (Fig. 3A).

NHE1 silencing decreases CCL25-induced migration in MOLT4 cells. CCL25 $(100 \mathrm{ng} / \mathrm{ml})$ induced an increase in migration of MOLT4 cells compared with the control group; however, when NHE1 expression was inhibited with cariporide in MOLT4 cells, the CCL25-triggered migration reduced significantly (Fig. 3B). This result demonstrated that NHE1 serves an important role in CCL25-induced migration in MOLT4 cells.

NHE1 knockdown increases the sensitivity of MOLT4 cells to DOX. Treatment of MOLT4 cells with $0.5 \mathrm{mg} / \mathrm{ml}$ and $1 \mathrm{mg} / \mathrm{ml}$ DOX demonstrated a significant increase in proliferation in the wild-type and scrambled siRNA groups compared with the NHE1 siRNA-silenced group (Fig. 4A and B). This observation suggested that NHE1 inhibition increased the sensitivity of MOLT4 cells to DOX. Blocking the effect of NHE1, may promote to an increased intracellular drug concentration and therefore a higher apoptosis rates in tumor cells.

Ezrin knockdown increases the accumulation of DOX in MOLT4 cells. The DOX accumulation in wild-type MOLT4 cells, represented by average fluorescence density, was decreased following CCL25 treatment. Conversely, CCL25 had no effect on DOX accumulation in Ev-ve MOLT4 cells (Fig. 4C and D). This result shows that ezrin is important in CCL25-induced DOX resistance.

\section{Discussion}

The etiology of T-ALL remains to be elucidated and it is hypothesized that multiple factors contribute towards its prevalence in childhood or in young adults (26). HTLV-1 infection is an established etiological factor, but the incidence rate of leukemia following this infection is low (27). Although it is a rare neoplasm, T-ALL is an aggressive disease that is characterized by a mature T-cell phenotype. Patients with this neoplasm, of whom a substantial number are children, have a poor prognosis following diagnosis $(20-22,28)$. Due to this, it is therefore important that effective treatment options are available to clinicians to optimally manage this disease. 
NHE1 has been implicated as serving notable roles in invasive and metastatic neoplastic tissue. In addition to increasing intracellular $\mathrm{pH}$ (6), NHE1 also binds to the cytoskeleton via ERM proteins and functions as a platform for signaling (19). The diverse functions of NHE1 make it a potential target for cancer treatment.

Ezrin is a member of the ERM family of linker proteins that link the cell membrane to the actin cytoskeleton. ERM proteins are negatively regulated by an intramolecular interaction between their $\mathrm{N}$ - and $\mathrm{C}$-terminal domains, which masks the actin- and membrane-binding sites (29). The sequential binding of phosphatidylinositol-4,5-bisphosphate and the phosphorylation of a conserved threonine residue (T567) are required for the activation of ezrin to enable its membrane-cytoskeleton linker function (30).

NHE1 is involved in cancer cell metastasis and invasion $(7,8,31,32)$. Therefore, the present study focused on NHE1 and its association with ezrin in MOLT4 cells. Firstly, the expression levels of NHE1 in wild-type and ezrin-silenced MOLT4 cells were assessed and a similar expression of NHE1 was observed in the two groups (data not shown). The effect of CCL25 on NHE1 and ezrin co-localization was observed and it was identified that the degree of co-localization was increased in the CCL25-treated group compared with the control group (Fig. 1). This may indicate that the complex formed by NHE1 and ezrin serves an important role in CCL25-induced MOLT4 transformation. The migratory and invasive ability of MOLT4 cells was assessed using scanning electron microscopy, in which it was observed the inhibition of NHE1 or ezrin led to a decrease in the polarization of MOLT4 cells. It was previously observed that the response of MOLT4 cells to CCL25 has a significant role in the metastasis and invasion of MOLT4 cells as they undergo polarization (12). The co-localization of NHE1 and ezrin, and the increased cell polarization observed supports the hypothesis that NHE1 functions in association with ezrin to transform MOLT4 cells into a metastatic phenotype. The results of the present study indicate that NHE1 may be providing structural support for the formation of a signaling complex involved in the movement of the cell. ERM proteins function by promoting NHE1 to connect actin with the cell membrane and form the structures that contributes to the alteration of the shape of the cell and its mobilization (3). Notably, ezrin has been demonstrated to act with NHE1 to link the actin cytoskeleton to the cell membrane (7). Ezrin is established to serve a notable role in leukemia and breast cancer, amongst other malignancies $(12,30)$. The present study demonstrates that NHE1 and ezrin may be involved in the transformation of MOLT4 cells and to the best of our knowledge this has not yet been described in the literature. The present study further emphasizes the role of NHE1 in tissue physiology and tumor pathogenesis (4).

The present study also assessed whether the treatment with CCL25 effected the expression of NHE1 and demonstrated that CCL25 upregulates NHE1 expression (Fig. 3A). This finding emphasizes the role of NHE1 as well as the role of chemokines in cancer cell mobilization. Furthermore, the chemotaxis assay (Fig. 3B) identified that CCL25 induced MOLT4 cell migration in an NHE1-dependent manner. In addition, the inhibition of NHE1 by the specific inhibitor cariporide resulted in the decreased chemotaxis of MOLT4 cells, despite CCL25 administration (Fig. 3B). These data clearly indicate the notable role of NHE1 in tumor migration and invasion.

To investigate the role of NHE1 in chemotherapeutic drug resistance of MOLT4 cells, the proliferation of cells treated with different concentrations of DOX was assessed in wild-type and NHE1-silenced MOLT4 cells. The findings of the present study demonstrate that proliferation was decreased in NHE1-silenced MOLT4 cells when exposed to a chemotherapeutic drug compared with control-treated MOLT4 cells (Fig. 4A and B). Man et al (3) established that NHE1 has a notable role in resistance to sorafenib in colon cancer cells. Therefore, blocking the effect of NHE1 may lead to a higher intracellular drug concentration and a higher apoptotic rate in tumor cells.

The present study reveals the potential role of ezrin in the development of chemotherapeutic drug resistance in MOLT4 cells. Ezrin-silenced cells did not differ considerably in DOX accumulation in the presence or absence of CCL25; however, the DOX accumulation of wild-type MOLT4 cells differed significantly in the presence and absence of CCL25 (Fig. 4C and D). The silencing of ezrin therefore appeared to maintain a higher intracellular drug concentration, thus improving the therapeutic effect.

In conclusion, the present study indicated that NHE1 and ezrin may, in combination, have notable roles in the metastasis and drug resistance of MOLT4 cells. These results inform on novel potential targets for T-ALL diagnosis and treatment. The treatment of T-ALL by blocking the activity NHE1 or ezrin may therefore be a viable treatment option for patients with this type of neoplasm.

\section{References}

1. Gómez AM, Martínez C, González M, Luque A, Melen GJ Martínez J, Hortelano S, Lassaletta, Á, Madero L and Ramírez M: Chemokines and relapses in childhood acute lymphoblastic leukemia: A role in migration and in resistance to antileukemic drugs. Blood Cells Mol Dis 55: 220-227, 2015.

2. Pitt LA, Tikhonova AN, Hu H, Trimarchi T, King B, Gong Y, Sanchez-Martin M, Tsirigos A, Littman DR, Ferrando AA, et al: CXCL12-producing vascular endothelial niches control acute $\mathrm{T}$ cell leukemia maintenance. Cancer Cell 27: 755-768, 2015.

3. Man CH, Lam SS, Sun MK, Chow HC, Gill H, Kwong YL and Leung AY: A novel tescalcin-sodium/hydrogen exchange axis underlying sorafenib resistance in FLT3-ITD+ AML. Blood 123: 2530-2539, 2014.

4. Amith SR and Fliegel L: Regulation of the $\mathrm{Na}+\mathrm{H}+$ exchanger (NHE1) in breast cancer metastasis. Cancer Res 73: 1259-1264, 2013. Slepkov ER, Rainey JK, Li X, Liu Y, Cheng FJ, Lindhout DA, Sykes BD and Fliegel L: Structural and functional characterization of transmembrane segment IV of the NHE1 isoform of the $\mathrm{Na}+\mathrm{H}+$ exchanger. J Biol Chem 280: 17863-17872, 2005.

5. Orlowski $\mathrm{J}$ and Grinstein S: Diversity of the mammalian sodium/proton exchanger SLC9 gene family. Pflugers Arch 447: 549-565, 2004.

6. Antelmi E, Cardone RA, Greco MR, Rubino R, Di Sole F, Martino NA, Casavola V, Carcangiu M, Moro L and Reshkin SJ: ß1 integrin binding phosphorylates ezrin at T567 to activate a lipid raft signalsome driving invadopodia activity and invasion. PLoS One 8: e75113, 2013.

7. Lin Y, Wang J, Jin W, Wang L, Li H, Ma L, Li Q and Pang T: NHE1 mediates migration and invasion of HeLa cells via regulating the expression and localization of MT1-MMP. Cell Biochem Funct 30: 41-46, 2012.

8. Denker SP, Huang DC, Orlowski J, Furthmayr H and Barber DL: Direct binding of the $\mathrm{Na}-\mathrm{H}$ exchanger NHE1 to ERM proteins regulates the cortical cytoskeleton and cell shape independently of $\mathrm{H}(+)$ translocation. Mol Cell 6: 1425-1436, 2000. 
9. Chiang Y, Chou CY, Hsu KF, Huang YF and Shen MR: EGF upregulates $\mathrm{Na}+\mathrm{H}+$ exchanger $\mathrm{NHE} 1$ by post-translational regulation that is important for cervical cancer cell invasiveness. J Cell Physiol 214: 810-819, 2008.

10. Cong D, Zhu W, Shi Y, Pointer KB, Clark PA, Shen H, Kuo JS, $\mathrm{Hu}$ S and Sun D: Upregulation of NHE1 protein expression enables glioblastoma cells to escape TMZ-mediated toxicity via increased $\mathrm{H}^{+}$extrusion, cell migration and survival. Carcinogenesis 35: 2014-2024, 2014

11. Zhou B, Leng J, Hu M, Zhang L, Wang Z, Liu D, Tong X, Yu B, $\mathrm{Hu}$ Y, Deng C, et al: Ezrin is a key molecule in the metastasis of MOLT4 cells induced by CCL25/CCR9. Leuk Res 34: 769-776, 2010.

12. Song X, Yang J, Hirbawi J, Ye S, Perera HD, Goksoy E, Dwivedi P, Plow EF, Zhang R and Qin J: A novel membrane-dependent on/off switch mechanism of talin FERM domain at sites of cell adhesion. Cell Res 22: 1533-1545, 2012.

13. Chen Y, Wang D, Guo Z, Zhao J, Wu B, Deng H, Zhou T, Xiang H, Gao F, Yu X, et al: Rho kinase phosphorylation promotes Ezrin-mediated metastasis in hepatocellular carcinoma. Cancer Res 71: 1721-1729, 2011.

14. Brambilla D, Zamboni S, Federici C, Lugini L, Lozupone F, De Milito A, Cecchetti S, Cianfriglia M and Fais S: P-glycoprotein binds to ezrin at amino acid residues 149-242 in the FERM domain and plays a key role in the multidrug resistance of human osteosarcoma. Int J Cancer 130: 2824-2834, 2012.

15. Zhang L, Xiao R, Xiong J, Leng J, Ehtisham A, Hu Y, Ding Q $\mathrm{Xu} \mathrm{H}$, Liu S, Wang J, et al: Activated ERM protein plays a critical role in drug resistance of MOLT4 cells induced by CCL25. PLoS One 1: e52384, 2013.

16. Ziętara N, Łyszkiewicz M, Puchałka J, Witzlau K, Reinhardt A, Förster R, Pabst O, Prinz I and Krueger A: Multicongenic fate mapping quantification of dynamics of thymus colonization. J Exp Med 212: 1589-1601, 2015.

17. Zlotoff DA, Sambandam A, Logan TD, Bell JJ, Schwarz BA and Bhandoola A: CCR7 and CCR9 together recruit hematopoietic progenitors to the adult thymus. Blood 115: 1897-1905, 2010

18. Qiuping Z, Jei X, Youxin J, Wei J, Chun L, Jin W, Qun W, Yan L, Chunsong H, Mingzhen Y, et al: CC chemokine ligand 25 enhances resistance to apoptosis in CD4+ T cells from patients with T-cell lineage acute and chronic lymphocytic leukemia by means of livin activation. Cancer Res 64: 7579-7587, 2004.

19. Jin W, Li Q, Lin Y, Lu Y, Li H, Wang L, Hu R, Ma L, Wang J and Pang T: Reversal of Imatinib resistance in BCR-ABL-positive leukemia after inhibition of the $\mathrm{Na}+\mathrm{H}+$ exchanger. Cancer Lett 308: 81-90, 2011.

20. Bourgeois S, Meer LV, Wootla B, Bloch-Faure M, Chambrey R, Shull GE, Gawenis LR and Houillier P: NHE4 is critical for the renal handling of ammonia in rodents. J Clin Invest 120: 1895-1904, 2010.
21. Chen $\mathrm{CH}$, Chen TH, Wu MY, Chen JR, Tsai HF, Hong LY, Zheng CM, Chiu IJ, Lin YF and Hsu YH: Peroxisome proliferator-activated receptor alpha protects renal tubular cells from gentamicin-induced apoptosis via upregulating $\mathrm{Na}+\mathrm{H}+$ exchanger NHE1. Mol Med: Nov 23, 2015 (Epub ahead of print).

22. Hojo T: Specimen preparation of the human cerebellar cortex for scanning electron microscopy using a t-butyl alcohol freeze-drying device. Scanning Microsc Suppl 10: 345-348, 1996.

23. Deng X, Tu Z, Xiong M, Tembo K, Zhou L, Liu P, Pan S, Xiong J, Yang X, Leng J, et al: Wnt5a and CCL25 promote adult T-cell acute lymphoblastic leukemia cell migration, invasion and metastasis. Oncotarget 8: 39033-39047, 2017.

24. Dang I, Gorelik R, Sousa-Blin C, Derivery E, Guérin C, Linkner J, Nemethova M, Dumortier JG, Giger FA, Chipysheva TA, et al: Inhibitory signalling to the Arp2/3 complex steers cell migration. Nature 503: 281-284, 2013.

25. Girardi T, Vicente C, Cools J and De Keersmaecker K: The genetics and molecular biology of T-ALL. Blood 129: 1113-1123, 2017.

26. Tsukasaki K and Tobinai K: Human T-cell lymphotropic virus type I-associated adult T-cell leukemia-lymphoma: New directions in clinical research. Clin Cancer Res 20: 5217-5225, 2014.

27. Beldjord K, Chevret S, Asnafi V, Huguet F, Boulland ML, Leguay T, Thomas X, Cayuela JM, Grardel N, Chalandon Y, et al: Oncogenetics and minimal residual disease are independent outcome predictors in adult patients with acute lymphoblastic leukemia. Blood 123: 3739-3749, 2014.

28. Fehon RG, McClatchey AI and Bretscher A: Organizing the cell cortex: The role of ERM proteins. Nat Rev Mol Cell Biol 11: 276-287, 2010.

29. Babich V and Di Sole F: The Na+/H+ exchanger-3 (NHE3) activity requires ezrin binding to phosphoinositide and its phosphorylation. PLoS One 10: e0129306, 2015.

30. Yang X, Wang D, Dong W, Song Z and Dou K: Over-expression of $\mathrm{Na}+\mathrm{H}+$ exchanger 1 and its clinicopathologic significance in hepatocellular carcinoma. Med Oncol 27: 1109-1113, 2010.

31. Yang $X$, Wang D, Dong W, Song Z and Dou K: Inhibition of $\mathrm{Na}(+) / \mathrm{H}(+)$ exchanger 1 by 5 -(N-ethyl-N-isopropyl) amiloride reduces hypoxia-induced hepatocellular carcinoma invasion and motility. Cancer Lett 295: 198-204, 2010.

32. Hoskin V, Szeto A, Ghaffari A, Greer PA, Côté GP and Elliott BE: Ezrin regulates focal adhesion and invadopodia dynamics by altering calpain activity to promote breast cancer cell invasion. Mol Biol Cell 26: 3464-3479, 2015. 